\title{
THE EFFECT OF THE CHRONIC ADMINISTRATION OF DPP4- INHIBITORS ON SYSTEMIC OXIDATIVE STRESS IN RATS WITH DIABETES TYPE 2
}

\author{
Stefani Bolevich ${ }^{1}$, Isidora Milosavljevic ${ }^{2}$, Nevena Draginic ${ }^{2}$, Marijana Andjic ${ }^{2}$, Nevena Jeremic ${ }^{2}$, Sergey Bolevich ${ }^{3}$, Peter F Litvitsky ${ }^{1}$ \\ and Vladimir Jakovljevic ${ }^{3,4}$ \\ ${ }^{1}$ 1st Moscow State Medical University I.M. Sechenov, Department of Pathophysiology, Moscow, Russian Federation \\ ${ }^{2}$ University of Kragujevac, Faculty of Medical Sciences, Department of Pharmacy, Kragujevac, Serbia \\ ${ }^{3} 1$ st Moscow State Medical University I.M. Sechenov, Department of Human Pathology, Moscow, Russian Federation \\ ${ }^{4}$ University of Kragujevac, Faculty of Medical Sciences, Department of Physiology, Kragujevac, Serbia \\ UTICAJ HRONIČNE PRIMENE DPP4-INHIBITORA NA SISTEMSKI \\ OKSIDACIONI STRES KOD PACOVA SA DIJABETESOM TIP 2 \\ Stefani Bolevich ${ }^{1}$, Isidora Milosavljević², Nevena Draginić ${ }^{2}$, Marijana Anđić², Nevena Jeremić ${ }^{2}$, Sergey Bolevich ${ }^{3}$, Peter F Litvitsky ${ }^{1}$ \\ i Vladimir Jakovljević $\mathbf{c}^{3,4}$

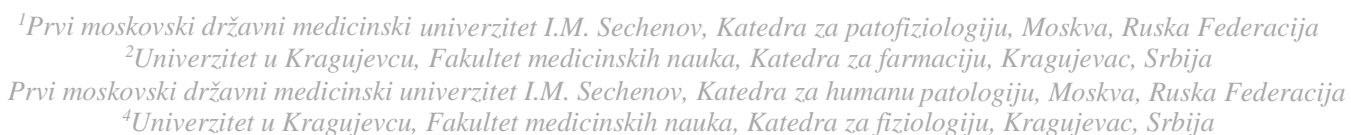

Received/Primljen: 14.08.2019.

Accepted/Prihvaćen: 17.08.2019.

\section{ABSTRACT}

Type 2 diabetes (T2DM) is characterized by well-preserved insulin secretion; however, the surrounding tissue is insensitive to insulin, resulting in increased blood glucose level due to the inability of tissues to convert glucose into energy. As a result of chronic non-regulation of glucose levels and high daily fluctuations in the blood, the micro- and macrovascular complications occur in these patients. Complications develop through two main mechanisms: induction of oxidative stress and innate immunity. In this regard, the aim of this study was to examine the effect of four week administration of DPP4 inhibitors (saxagliptin, sitagliptin and vildagliptin) to the parameters of oxidative stress and antioxidant defense in the group of rats with diabetes type 2 (T2DM). Sixty Wistar albino rats were divided randomly into 5 groups: group I: control healthy group; group II: rats with diabetes type 2; group III: rats with diabetes type 2 treated with 0.6 $\mathrm{mg} / \mathrm{kg}$ of sitagliptin; group IV: rats with diabetes type 2 treated with $0.45 \mathrm{mg} / \mathrm{kg}$ of saxagliptin, group V: rats with diabetes type 2 treated with $9 \mathrm{mg} / \mathrm{kg}$ vildagliptin. The rats from experimental groups were fed with a high-fat diet for 4 weeks and after $6-8 \mathrm{~h}$ of starvation received one dose of streptozotocin (STZ) intraperitoneally (25 mg/kg body weight) to induce T2DM. Animals with fasting glucose above $7 \mathrm{mmol} / \mathrm{L}$ and insulin over $6 \mathrm{mmol} / \mathrm{L}$ were included in the study as rats with T2DM. Upon completion of the experiments, the blood was collected from the anesthetized animals and used for sphectrophotometrical determination of parameters of oxidative stress, and antioxidative defense. T2DM induced significant increase in production of reacitve oxygen species (ROS) (superoxide anion radical and hydrogen peroxide), but additional four-week administration of gliptins induced decrease in ROS values. On the other hand, T2DM induced decrease of nitric oxide, superoxide dismutase, catalaze, and reduced gluthation and concomitant therapy with gliptins induced increase of these parametars, suggesting significant antioxidant potential of this group of drugs.

Keywords: type 2 diabetes, saxagliptin, sitagliptin, vildagliptin, oxidative stress, antioxidant protection
SAŽETAK

Dijabetes tip 2 (T2DM) karakteriše očuvana sekrecija insulina; međutim okolno tkivo je neosetljivo na dejstvo insulina, što dovodi do povećanja nivoa glukoze usled nemogućnosti tkiva da pretvori glukozu u energiju. Kao posledica hronične neregulacije nivoa glukoze i visokih dnevnih fluktuacija u krvi, mikro- i makrovaskularne komplikacije se javljaju kod ovih pacijenata. Komplikacije se razvijaju kroz dva osnovna mehanizma: indukciju oksidacionog stresa i urođenog imuniteta. S tim u vezi, cilj ove studije bio je da se ispita efekat primene dipeptidil-peptidaza 4 (DPP4)-inhibitora saksagliptina, sitagliptina i vildagliptina na parametre oksidacionog stresa i antioksidacione odbrane u grupi pacova sa dijabetesom tip 2. Šezdeset Wistar albino pacova je nasumično podeljeno u 5 grupa: grupa I: kontrolna zdrava grupa; grupa II: pacovi sa dijabetesom tip 2; grupa III: pacovi sa dijabetesom tip 2 tretirani sa 0,6 mg/kg sitagliptina; grupa IV: pacovi sa dijabetesom tip 2 tretirani sa $0,45 \mathrm{mg} / \mathrm{kg}$ saksagliptina, grupa V: pacovi sa dijabetesom tip 2 tretirani sa $9 \mathrm{mg} / \mathrm{kg}$ vildagliptina. Pacovi iz eksperimentalnih grupa su 4 nedelje hranjeni hranom sa visokim sadržajem masti, a potom su nakon 6-8 sati gladovanja primili jednu dozu streptozotocina (STZ) intraperitonealno (25 mg/kg telesne težine) kako bi se indukovao T2DM. U dalju studiju su uključene životinje sa glukozom natašte iznad 7 $\mathrm{mmol} / \mathrm{L}$ i insulinom preko $6 \mathrm{mmol} / \mathrm{L}$, kao pacovi koji su razvili T2DM. Po završetku eksperimenata, krv je sakupljena od anesteziranih životinja i korišćcna za spektrofotometrijsko određivanje parametara oksidacionog stresa i antioksidacione zaštite. T2DM je indukovao značajno povećanje proizvodnje reaktivnih kiseoničnih vrsta (ROS) (superoksid anjon radikal $i$ vodonik peroksid), ali sa druge strane četvoronedeljna primena gliptina je dovela do smanjenja vrednosti ROS. Dodatno, T2DM je indukovao smanjenje azotmonoksida, superoksid dismutaze, katalaze i redukovanog glutationa, dok su gliptini doveli do povećanja ovih parametara, što govori u prilog značajnom antioksidacionom potencijalu ove grupe lekova.

Ključne reči: dijabetes tip 2, saksagliptin, sitagliptin, vildagliptin, oksidacioni stres, antioksidaciona zaštita 


\section{INTRODUCTION}

Diabetes belongs to a group of metabolic diseases whose main characteristic is hyperglycaemia due to the lack of secretion and/or action of insulin (1). The prevalence of this disease globally is around $8.3 \%$, or as many as 415 million people are already diagnosed with diabetes and this number is increasing year by year especially in the developed countries (2). Diabetes Mellitus type 2 is much more common (95\% of people have this type of diabetes). There is insulin secretion, but the surrounding tissue is insulininsensitive, which results in an increase in glucose levels due to the tissue's inability to convert the available glucose into energy (3).

As a consequence of chronic non-regulation of glucose levels and high daily glucose fluctuations, micro- and macrovascular complications occur in these patients in a high percentage (4). Complications arise through two basic mechanisms: induction of oxidative stress and induction of innate immunity $(5,6)$. More recent studies have shown that daily fluctuations in glucose levels contribute much more to the onset of oxidative stress than chronic hyperglycemia (7). Due to the foregoing, all factors must be taken into account in order to achieve adequate control when administering antidiabetics. It is unknown whether drugs that regulate daily glucose fluctuations would have any specific benefits (reduction of oxidative stress and inflammation) compared to conventional therapy monitoring glycated hemoglobin levels as the gold standard of glycemic control. Oxidative stress in diabetes occurs as a consequence of free radical formation due to glucose oxidation, non-enzymatic glycosylation of proteins, and oxidative degradation of glycolized proteins $(8,9)$.

Traditionally, metformin has been used as the first drug of choice in these conditions; however, its effectiveness decreases with age, so it is necessary to administer a large number of drugs for good glycemic control (10). Gliptins (dipeptidyl peptidase 4 - DPP4 inhibitors) represent one of the additional drug groups used in diabetes therapy. Since the introduction of sitagliptin in clinical practice, DPP4 inhibitors have been increasingly used in Diabetes Mellitus type 2 therapy. DPP4 inhibitors have been a large diverse group of drugs, divided into two narrow groups: peptidomimetics (e.g. saxagliptin and vildagliptin) and non-peptidomimetics (e.g. sitagliptin). Both of these groups act as competitive reversible inhibitors of DPP4, with peptidomimetics containing a nitrile group and forming a reversible covalent bond between drug and enzyme, the drug gradually and slowly dissociates from the complex to achieve long-term inhibitory activity, even after drug inactivation. On the other hand, non-peptidomimetics create non-covalent bonds with the catalytic domain of the enzyme, producing strong and immediate inhibition $(11,12)$. The difference in structure not only leads to a difference in the mechanism of action, but also to a difference in their metabolic pathways, as well as in the dosage range and dosage regimen (13). Given the fact that there are differences in daily fluctuations in glucose levels in patients using different DPP4 inhibitors, the question is whether the organism's response to oxidative stress in these patients is also different (14). In this regard, the aim of this study was to investigate the effect of administration of different drugs from the DPP4 inhibitor group on the parameters of oxidative stress and antioxidant protection in animals with type 2 diabetes.

\section{MATERIALS AND METHODS}

\section{The material used in the study}

Streptozotocin $\quad(\mathrm{MW}=265.221), \quad$ sitagliptin $\quad(\mathrm{MW}=$ 523.32), saxagliptin (MW = 315.41) and vildagliptin (MW= 303.399) were purchased from Sigma-Aldrich Chemie GmbH Eschenstr. 5, 82024 Taufkircen, Germany.

\section{Induction of Diabetes Mellitus Type 2}

In the experimental protocol, 6-week-old animals were used (average body weight of $200 \pm 20$ grams). To induce type 2 diabetes, the animals were fed a high fat diet (HFd) for four weeks. After 4 weeks on $\mathrm{HFd}$ and after a 12-hour overnight fast, streptozotocin was administered at a single dose of $25 \mathrm{mg} / \mathrm{kg}$. Three days (72 hours) later, glucose and insulin were measured. Animals with a fasting blood glucose level more than $7 \mathrm{mmol} / \mathrm{L}$ and the fasting insulin level above $6 \mathrm{mg} / \mathrm{dL}$ were included in the study and were considered as the rats with type 2 diabetes $(15,16)$.

\section{The experimental treatment protocol for DPP4 inhibitors}

Animals that developed diabetes type 2 (according to the previously described criteria), were divided into four experimental groups and one control group. Animals in the experimental groups (3 of 4) received DPP4 inhibitors intraperitoneally once daily for three weeks at the following doses: sitagliptin $0.6 \mathrm{mg} / \mathrm{kg}$ body weight, saxagliptin 0.45 $\mathrm{mg} / \mathrm{kg}$ body weight, vildagliptin $9 \mathrm{mg} / \mathrm{kg}$ body weight. The last experimental group was not treated pharmacologically.

\section{Experimental groups}

Male Wistar albino rats, 60 animals (12 per group), were used for the study. Animals were housed in cages (four in each) in a vivarium with controlled conditions of humidity, temperature (22 $\pm 20 \mathrm{~S})$ and light (12/12 hour light / dark cycle). At the time of completion of the experimental protocol, all animals were 13 weeks old. Animals were divided into five groups. The first group consisted of healthy animals using the standard diet (9\% fat, 20\% protein, 53\% starch, $5 \%$ fiber), the remaining four groups consisted of type 2 diabetic animals using the high fat diet (25\% fat, 15\% protein, 51\% starch, 5\% fiber). In these four groups the animals differed in pharmacological treatment. 
Groups:

1. Healthy Animals - Con

2. Animals with type 2 diabetes without pharmacological treatment - DM

3. Animals with type 2 diabetes and $0.6 \mathrm{mg} / \mathrm{kg}$ bodyweight sitagliptin therapy - DM + Sit

4. Animals with type 2 diabetes and $0.45 \mathrm{mg} / \mathrm{kg}$ body weight saxagliptin therapy - DM + Sak

5. Animals with type 2 diabetes and therapy and vildagliptin $9 \mathrm{mg} / \mathrm{kg}$ body weight - DM + Vld

\section{Biochemical analyses}

After completing experimental protocol, which lasted seven weeks, anesthetized animals were bled for analysis of parameters of oxidative stress and antioxidant protection. Citrate glass tubes were used for blood sampling. Immediately after collecting the sample, the sample is centrifuged to separate plasma, while the rest is rinsed in order to obtain a lysate of erythrocytes to determine the parameters of the antioxidative protection. The samples thus obtained were stored at $-80^{\circ} \mathrm{C}$ until carrying out the predicted analyzes.

Plasma was used for the determination of oxidative stress markers; in these samples the concentrations of the tested parameters were determined as follows:

- the determination of superoxide anion radical (O2-) - is based on the reaction of $\mathrm{O}_{2}{ }^{-}$with nitro blue tetrazolium (Nitro Blue Tetrazolium - NBT) to nitroformazan blue. The measurement is performed at a wavelength $\lambda=550 \mathrm{~nm}$ (17).

- hydrogen peroxide determination $\left(\mathrm{H}_{2} \mathrm{O}_{2}\right)$ - is based on the oxidation of phenol red by hydrogen peroxide. This reaction is catalyzed by the horse radish peroxidase enzyme (HorserRadishPerOxidase - HRPO). This reaction results in the formation of a compound whose absorption maximum at a wavelength $\lambda=610 \mathrm{~nm}$ (18).

- determination of nitrite $\left(\mathrm{NO}_{2}^{-}\right)$- is based on the use of the Griess reagent, which builds with nitrites diazo-violet complex. After color stabilization at room temperature for 510 minutes approach to determining the concentration of nitrite liberated by spectrophotometry at a wavelength of $\lambda=$ $550 \mathrm{~nm}$ (19).

- determination of lipid peroxidation index (TBARS) - is based on indirect determination by detection of the products of the lipid peroxidation reaction with thiobarbituric acid, hence the abbreviation TBARS (Thiobarbituric Acid Reactive Substances). The method is based on the determination of lipid peroxide levels based on the reaction of one of them, malonildialdehyde (MDA) with thiobarbituric acid (TBA) Determination is carried out spectrophotometrically at a wavelength of $\lambda=530 \mathrm{~nm}$ (20).

For the determination of markers of antioxidant defense, a lysate of erythrocytes is used; in these samples the concentrations of test parameters were determined on the following way:
- determination of catalase activity (CAT) - after dilution of lysate with distilled water in a ratio of $1: 7$ and addition of ethanol in a ratio of 0.6 : 1 , a further procedure was started. $50 \mu \mathrm{l}$ of CAT buffer, $100 \mu \mathrm{l}$ of sample and $1 \mathrm{ml}$ of $10 \mathrm{mM} \mathrm{H}_{2} \mathrm{O}_{2}$ were placed in a test tube and measurement of samples at $\lambda=360 \mathrm{~nm}$ wavelength was started (21).

- determination of superoxide dismutase (SOD) activity is carried out by the epinephrine method according to Beutler. Mixing $100 \mathrm{ml}$ of lysate and $1 \mathrm{ml}$ of carbonate buffer, initiating the process, followed by the addition of $100 \mathrm{ml}$ of epinephrine. Measurements are made spectrophotometrically at a wavelength $\lambda=470 \mathrm{~nm}$ (22).

- determination of reduced glutathione (GSH) - is based on the reaction of glutathione oxidation with 5,5-dithiobis-6,2-nitrobenzoic acid, by the Beutler method. The activity of the antioxidant molecule of reduced glutathione was measured by a spectrophotometric method at a wavelength $\lambda=450 \mathrm{~nm}$ (23).

\section{Statistical data processing}

To test for differences between parameters, depending on their statistical normality, Student's t-test, Paired t-test, Mann-Whitney test, Fisher's absolute probability test, onefactor or two-factor analysis of variance will be used. When testing the difference between the parameters, in the case of the existence of multiple sub-groups, Bonferroni test is used. Statistical analysis was performed in the statistical package SPSS 20.0 for Windows (Statistical Package for the Social Sciences).

\section{RESULTS}

\section{Effect of chronic DPP4 inhibitor administration on oxidative stress parameters}

Induction of type 2 diabetes led to a decrease in the value of indirectly measured nitrite monoxide (Figure 1A). However, a four-week administration of all three drugs from the DPP4 inhibitor group resulted in an increase in nitrite values, which were statistically significantly higher than the control (Figure 1A). The highest nitrite value was observed in the rat group treated with sitagliptin. However, this value was not statistically higher than in the groups treated with the remaining two drugs (Figure 1A). Induction of type 2 diabetes led to a significant increase in the value of superoxide anion radical relative to healthy animals without diabetes (Figure 1B). Four weeks administration of all three drugs from the DPP4 inhibitor group resulted in a significant decrease in the superoxide anion radical value (Figure $1 \mathrm{~B}$ ). All three drugs reduced the levels of superoxide anion radicals, but this time there were differences in their effects, the greatest decrease was observed in the vildaglitin group, while sitagliptin showed the smallest effect on the decrease of these values, which was significant (Figure 1B). Although all three drugs reduced the levels of superoxide anion radicals, none of the 
mentioned drugs managed to override these values sufficiently to bring them closer to the values measured in the group of healthy animals (Figure 1B). Induction of type 2 diabetes also led to an increase in hydrogen peroxide values relative to the values of this parameter in non-diabetic animals (Figure 1C). Four weeks administration of all three drugs in the DPP4 inhibitor group led to a significant decrease in the value of hydrogen peroxide (Figure 1C). There was a significant difference in the effects of saxagliptin relative to sitagliptin and vildagliptin; namely, saxagliptin led to the slightest decrease in hydrogen peroxide values (Figure 1C). None of these three applied DPP4 inhibitors succeeded to reduce the values of hydrogen peroxide to those measured in the control group (Figure 1C). Index of lipid peroxidation did not differ significantly between groups, regardless of disease induction and administration of DPP4 inhibitor values remained similar to those in healthy animals.

Figure 1. The effects of DPP-4 inhibitors on systemic oxidative stress parameters
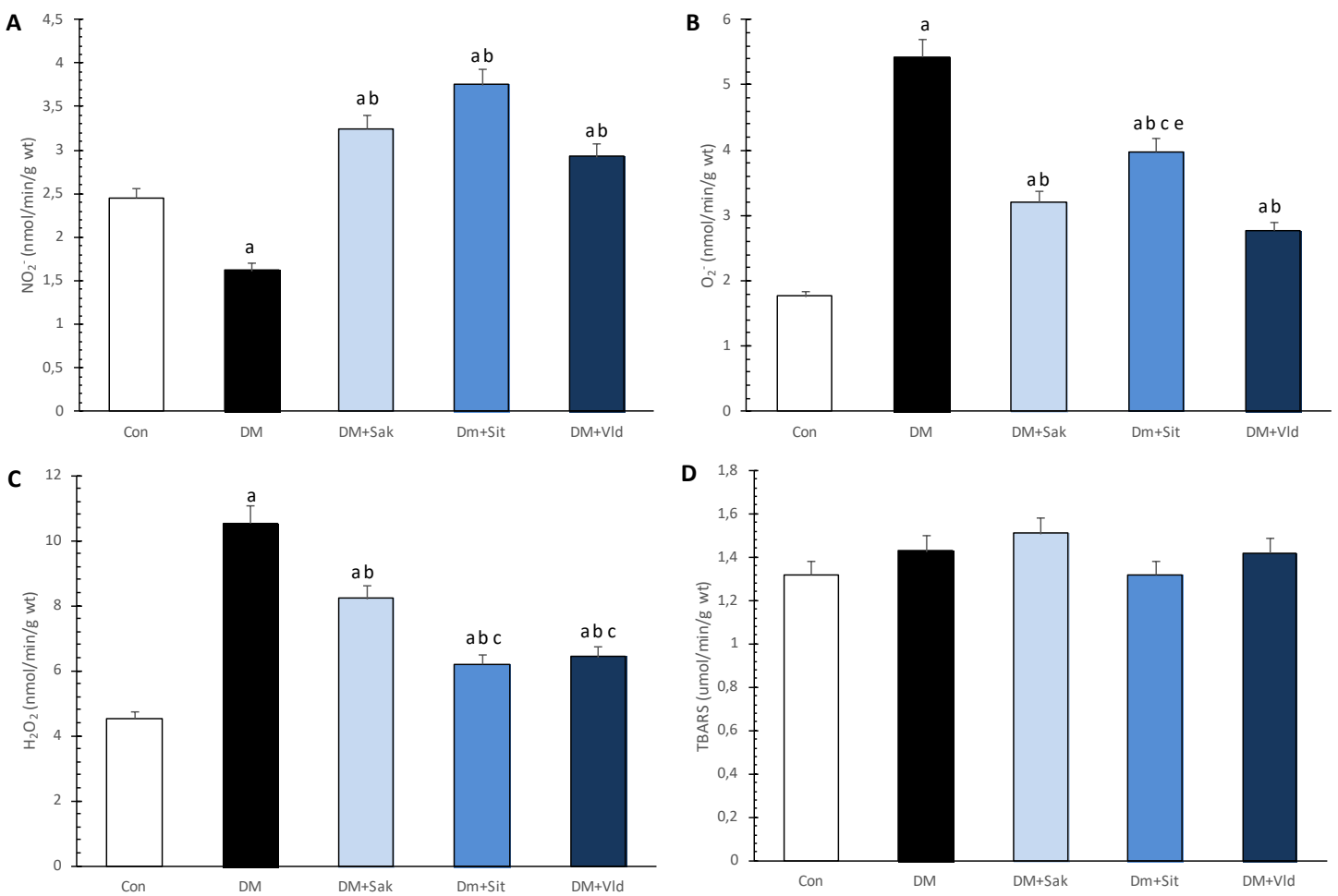

a - statistical significance of other groups in relation to control; b - statistical significance of other groups in relation to DM; c - statistical significance of other groups with respect to DM + sak; d - statistical significance of other groups with respect to DM + sit; e - statistical significance of other groups with respect to DM + vld. Results of mean $\pm \mathrm{SD}, \mathrm{n}=12$ per group are presented.

\section{The effect of chronic administration of DPP4 inhibitors on antioxidant protection parameters}

Induction of type 2 diabetes led to a significant decrease in the value of superoxide dismutase relative to the control group (Figure 2A). Administration of all three drugs from the DPP4 inhibitor group led to a statistically significant increase in superoxide dismutase (Figure 2A). However, it failed to completely nullify the effects resulting from type 2 diabetes, i.e. despite the administration of drugs, the levels of superoxide disumtase in these groups were significantly lower than the values of this enzyme in the control group (Figure 2A). Comparing the effects of DPP4 inhibitors, it was observed that administration of sitagliptin led to the greatest increase in superoxide dismutase values, while the remaining two DPP4 inhibitors had a similar effect on the production of this enzyme (Figure 2A). Almost identical trend was observed for catalase activity (Figure 2B). The induction of diabetes led to a decrease in catalase activity, and administration of a DPP4 inhibitor was able to increase catalase activity (Figure 2B). However, as with superoxide dismutase, the catalase values failed to return to baseline values, respectively, which were recorded in the control group where healthy animals were (Figure 2B). Induction of type 2 diabetes led to a decrease in the value of reduced glutathione (Figure $2 \mathrm{~V}$ ). Administration of all three drugs from the DPP4 inhibitor group resulted in a statistically significant increase in the reduced glutathione value (Figure 2V). However, similar to the two antioxidant 
protection parameters described above, the reduced glutathione values were lower in these groups compared to the reduced glutathione values observed in the healthy rat group
(Figure 2V). Comparison of the effects of DPP4 inhibitor on the reduced glutathione values did not show any significant difference between the drugs in this group (Figure 2V).

Figure 2. Changes in blood pressure and heart rate in healthy and rats with T2DM
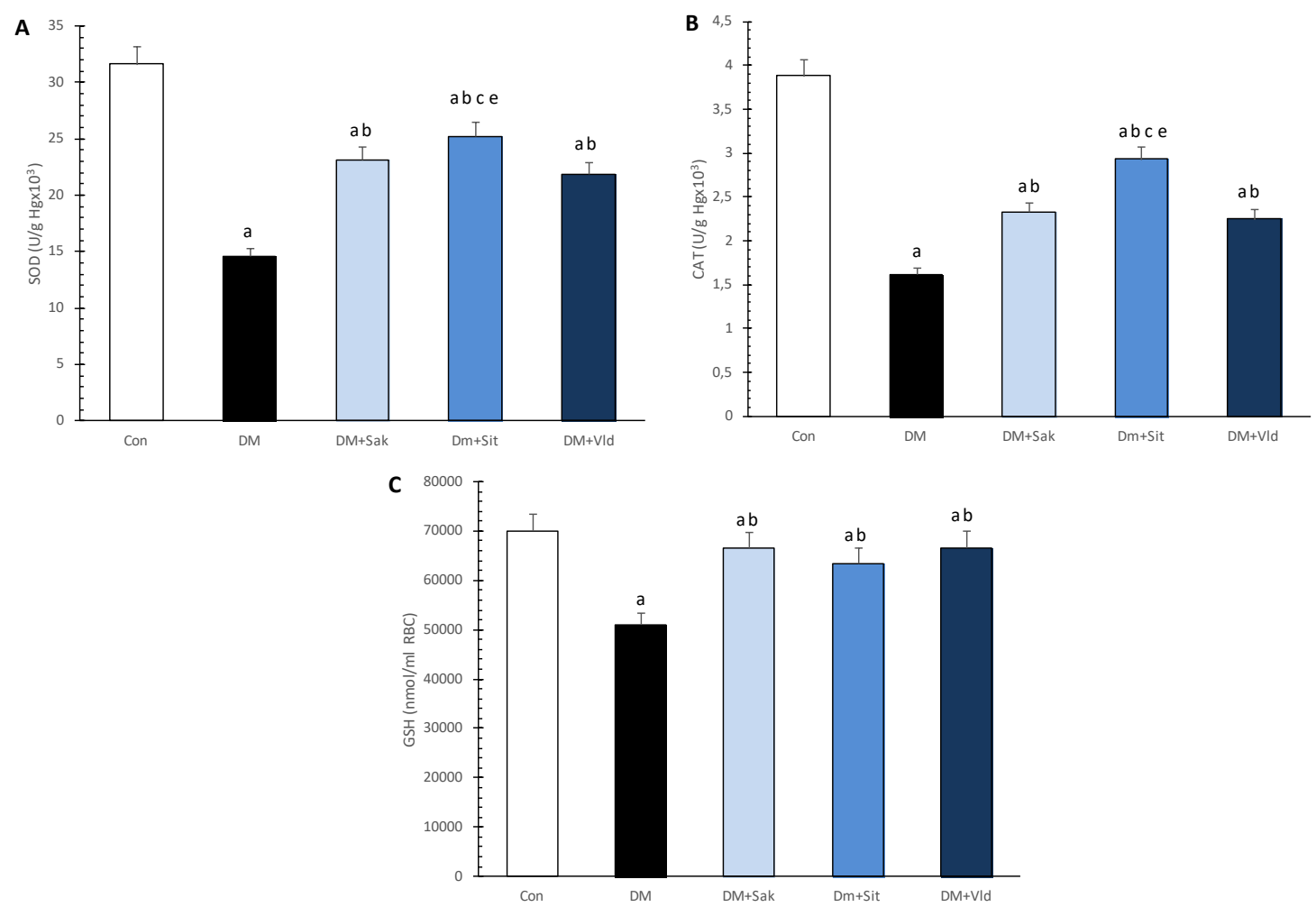

\begin{abstract}
a - statistical significance of other groups in relation to control; b - statistical significance of other groups in relation to DM; c - statistical significance of other groups with respect to DM + sak; d - statistical significance of other groups with respect to DM + sit, e - statistical significance of other groups with respect to DM + vld.
\end{abstract} Results of mean $\pm \mathrm{SD}, \mathrm{n}=12$ per group are presented.

\title{
DISCUSSION
}

Type 2 diabetes (T2DM) is a complex multifactorial metabolic disorder characterized by abnormal metabolism of carbohydrates, fats and proteins leading to increased levels of glucose and lipids in the blood (24). Chronic exposure to elevated glucose and lipid levels triggers different pathways responsible for inducing decreased insulin secretion from pancreatic $\beta$-cells, insulin resistance in peripheral tissues, decreased glucose utilization in peripheral tissues, and pathophysiological production of glucose in the liver (25). In addition, there is evidence that T2DM is associated with numerous complications and strongly influences the development of hypertension and other cardiovascular diseases. Therefore, it is very important to identify the molecular mechanisms associated with the onset of diabetes in order to develop targeted and effective therapies to treat this complex disease and prevent potential complications (26)

The results of clinical studies indicate that oxidative stress is strongly associated with the prevalence of type 2 diabetes. Biomarkers of tissue damage such as oxidation of DNA molecule bases, 4-hydroxy-2-nonelane (HNE) protein, hydroperoxides, 8-hydroxy-deoxyguanine and 8-epi-prostaglandin $F 2 \alpha$, were elevated in plasma and pancreatic samples of patients with type 2 diabetes $(27,28)$. Experimental studies have shown that total antioxidant potential (TAS) is significantly reduced in T2DM, while levels of peroxide and other biomarkers of oxidative stress are significantly increased (29). The results of our study showed that rats with type 2 diabetes had high levels of measured reactive oxygen species (ROS), superoxide anion radicals, and hydrogen 
peroxide (Figure 1B and 1C). ROS are one of the main species that propagate the onset of oxidative stress and normally are created in the body as a by-product of metabolism. Specifically, the superoxide anion radical is formed during the cellular respiration process, where free electrons are released from the mithondria, which subsequently binds to molecular oxygen in the presence of the NADPH oxidase enzyme to form $\mathrm{O}_{2}{ }^{-}(30,31)$. Under physiological conditions, $\mathrm{O}_{2}{ }^{-}$does not exhibit toxic effects because the enzyme superoxide dismutase (SOD) converts it to the less toxic hydrogen peroxide $\mathrm{H}_{2} \mathrm{O}_{2}$ (31). The results of our study showed that in rats with T2DM there was also a strong increase in $\mathrm{H}_{2} \mathrm{O}_{2}$ (Figure 1C), with a dramatic decrease in the value of the SOD enzyme (Figure 2A). These results undoubtedly support the onset of oxidative stress due to the development of T2DM, as the activity of the SOD enzyme, which represents the first line of defense against the uncontrolled generation of reactive oxygen species was reduced, which results in elevated values of these markers. In addition to the decreased values of the SOD enzyme, a decrease in the activity of catalase (SAT), an enzyme representing the second line of defense against free radicals, was observed in our study in rats with T2DM (Figure 2B). Namely CAT converts hydrogen peroxide to water and molecular oxygen (32). Due to the reduced activity of the SOD enzyme and the consequent accumulation of $\mathrm{O}_{2}^{-}$, it binds to nitrogen monoxide and produces even more toxic peroxynitrite (33). The results of our studies confirm this fact, because in rats with T2DM lower nitrite values were measured, representing an indirect measure of the released vasodilator molecule of nitrogen monoxide (Figure 1C). In our study, peroxynitrite values were not measurable, which may be one of the disadvantages to to accurately observe the whole situation; however, the reduced NO values with elevated $\mathrm{O}_{2}^{-}$undoubtedly support the assumption that even more toxic peroxynitrite molecules were formed. With such increased ROS and reduced NO values, intensive lipid peroxidation would be expected (34); however, the results of our study did not show a statistically significant increase in index of lipid peroxidation, measured as TBARS (Figure 1D). A potential explanation for such TBARS values may be the insufficient duration of the disease (7 weeks) before sampling, and it is hypothesized that with progression of the disease these values would also increase. Glutathione (GSH), is the primary intracellular antioxidant and has been extensively studied in populations with T2DM. Murakami and coworkers have shown that in patients with T2DM there are low values of the reduced form of GSH, while the levels of the oxidized form of GSSG are very high (35). Our study confirmed the low values of the reduced GSH form (Figure 2C).

In patients with T2DM, therapy is traditionally initiated with oral hypoglycemic metformin, which is a biguanidine derivative. However, over time, the efficacy of this drug has declined, and over the years the proportion of patients with successful glycemic control has been shown to decrease. Namely, after three years of metformin treatment, $50 \%$ of patients manage to regulate glucose levels, while after 9 years the number of these patients further decreases dramatically and drops to $25 \%$ (36). For these reasons, combination therapy is required and most often for years as adjunct therapy some of the sulfonylurea derivatives were introduced (37). A major drawback of this group of drugs is that they lead to the closure of ATR-dependent potassium channels, which can cause numerous side effects to the heart and thus further increase the risk of developing cardiovascular complications in T2DM (38). In this connection, it is very important to choose the appropriate therapy that, in addition to influencing glucose regulation, will influence the modification of potential complications. As we have already shown, T2DM strongly induces oxidative stress and drastically reduces antioxidant protection, and is one of the mechanisms for further development of complications. As we have already shown, T2DM strongly induces oxidative stress and drastically reduces antioxidant protection and is one of the mechanisms for further development of complications. Usage of drugs that, in addition to glucose levels, would have the effect of reducing oxidative stress and increasing antioxidant protection, would result in lower risk of complications. In this study, a group of drugs called DPP4 inhibitors was used. These drugs work by inhibiting the dipeptidyl peptidase 4 enzyme, thereby increasing levels of intestinal hormones, incretin: glucagon-like peptide 1 (GLP1), and gastric inhibitory polypeptide (GIP) (39). An additional aim of this study was to investigate whether administration of a DPP4 inhibitor in a rat population with T2DM can reduce the disease-induced oxidative stress, and to compare the effects of three different drugs in this group on the values of oxidative stress parameter and antioxidant protection. Sitagliptin, saxagliptin and vildagliptin were used in the study because they are known to have varying degrees of DPP4 enzyme inhibition (40).

All applied DPP4 inhibitors showed a significant influence on the parameters of oxidative stress and antioxidant protection (Figures 1, 2). However, there was a difference in their effects at certain parameters. Of all three drugs used in this group, vildagliptin had the strongest effect on reactive oxygen species (Figure 1B, 1C). Four weeks of intraperitoneal administration of this drug to T2DM rats was sufficient to lead to a statistically significant decrease in the values of these parameters and to approximate them as much as possible to the control group, i.e. group of healthy rats. This effect can be explained by the activation of the first and second antioxidant defense lines, respectively, by the increase in SOD and CAT activities, which were also observed in this group (Figures 2A, 2B). Sherif et al. showed that vildagliptin may increase CAT activity in the liver in rats with ischemic/reperfusion injury to this organ (41). The remaining two drugs also showed statistically significant reductions in reactive oxygen species (Figure 1B, 1C) and an increase in SOD and CAT values (Figure 2A, 2B). These results are in agreement with previous studies that have addressed the antioxidant potential of these drugs (42-45). In addition to affecting these two enzymes, all three drugs also increased the concentration of reduced glutathione, another of the antioxidant enzymes (Figure 1C). Among all tested drugs, sitaglitin (Figure 2A-C) showed the most positive effect on the activation of antioxidant protection. A potential explanation for this effect of 
sitagliptin might be that it belongs to a group of nonpeptidomimetics that form non-covalent bonds with the catalytic domain of DPP4 enzymes, producing strong and immediate inhibition $(11,12)$. Refaat and coworkers also demonstrated that administration of vildagliptin leads to an increase in the fraction of reduced glutathione in the liver in T2DM rats (46). Similar effects of sitagliptin on GSH in the liver have been demonstrated by El-Kashef et al (42). Saxagliptin and its effects on reduced glutathione have been studied so far in animal models at the kidney level (44). All three drugs resulted in increased synthesis of nitrogen monoxides; the value of this parameter was even higher in the T2DM-treated rat groups treated with any of the DPP4 inhibitors than in the healthy rat group. This is a very interesting finding because it indicates the great potential of these drugs to lead to vasodilation, which is a very important cardioprotective effect. It has already been mentioned that a large number of antidiabetics show negative effects on the cardiovascular system (37, 38).

To our knowledge, this is the first study concerning the systemic effect of DPP4 inhibitors on oxidative stress in T2DM rats. (a) As expected, rats with T2DM had elevated values of oxidative stress parameters and decreased antioxidant protection parameters values. (b) All investigated DPP4 inhibitors reduced oxidative stress and increased antioxidant protection. (c) Vildagliptin showed the highest reduction of oxidative stress, (d) while sitagliptin led to the greatest jump in antioxidant protection. (e) All three drugs showed great potential as vasodilators.

\section{REFERENCES}

1. Ryden L, Grant PJ, Anker SD, Berne C, Cosentino F, Danchin N, Deaton C, Escaned J, Hammes HP, Huikuri H, Marre M, Marx N, Mellbin L, Ostergren J, Patrono C, Seferovic P, Uva MS, Taskinen MR, Tendera M, Tuomilehto J, Valensi P, Zamorano JL. ESC guidelines on diabetes, pre-diabetes, and cardiovascular diseases developed in collaboration with the EASD - summary. Diab Vasc Dis Res. 2014;11(3):133-73.

2. Hoch E, Rusu V, Schreiber SL, Florez JC, Jacobs SB, Lander ES. Type 2 diabetes-associated variants disrupt function of SLC16A11, a proton-coupled monocarboxylate transporter, through two distinct mechanisms, Faseb J. 2017; 31.

3. Cowan J. Overview of Type 2 Diabetes. Essentials of SGLT2 Inhibitors in Diabetes, Springer, 2017.

4. Monnier L, Lapinski H, Colette C. Contributions of fasting and postprandial plasma glucose increments to the overall diurnal hyperglycemia of type 2 diabetic patients: variations with increasing levels of HbA (1c). Diabetes Care 2003; 26:881-5.

5. Brownlee M. Biochemistry and molecular cell biology of diabetic complications.Nature 2001; 414:813-20.

6. Esposito K, Nappo F, Marfella R, Giugliano G, Giugliano F, Ciotola M, Quagliaro L, Ceriello A, Giugliano D.
Inflammatory cytokine concentrations are acutely increased by hyperglycemia in humans: role of oxidative stress. Circulation 2002; 106:2067-72.

7. Monnier L, Mas E, Ginet C, Michel F, Villon L, Cristol JP, Colette C. Activation of oxidative stress by acute glucose fluctuations compared with sustained chronic hyperglycemia in patients with type 2 diabetes. JAMA 2006; 295:1681-7.

8. Omotayo EO, Gurtu S, Sulaiman SA, Wahab MSA, Sirajudeen K, Salleh MSM. Hypoglycemic and antioxidant effects of honey supplementation in streptozotocin-induced diabetic rats, Int. J. Vitam. Nutr. Res. 2010; 80(1):74-82.

9. Maritim AC, Sanders RA, Watkins JB 3rd. Diabetes, oxidative stress, and antioxidants: a review. J Biochem Mol Toxicol. 2003; 17(1):24-38.

10. Nathan DM, Buse JB, Davidson MB, Ferrannini E, Holman RR, Sherwin R, Zinman B. Medical management of hyperglycemia in type 2 diabetes: a consensus algorithm for the initiation and adjustment of therapy: a consensus statement of the American Diabetes Association and the European Association for the Study of Diabetes. Diabetes Care. 2009; 32:193-203.

11. Gupta V, Kalra S. Choosing a gliptin. Indian J Endocrinol Metab. 2011; 15:298-308.

12. Deacon CF. Dipeptidyl peptidase- 4 inhibitors in the treatment of type 2 diabetes: a comparative review. Diabetes Obes Metab. 2011; 13:7-18.

13. Blech S, Ludwig-Schwellinger E, Grafe-Mody EU, Withopf B, Wagner K. The metabolism and disposition of the oral dipeptidyl peptidase-4 inhibitor, linagliptin, in humans. Drug Metab Dispos. 2010; 38:667-78.

14. Marfella R, Barbieri M, Grella R, Rizzo MR, Nicoletti GF, Paolisso G. Effects of vildagliptin twice daily vs. sitagliptin once daily on 24-hour acute glucose fluctuations. J Diabetes Complications 2010; 24:79-83.

15. Reed, M.J., Meszaros, K., Entes, L.J., Claypool, M.D., Pinkett, J.G., Gadbois, T.M., and Reaven, G.M. 2000. A new rat model of type 2 diabetes: The fat-fed, streptozotocin-treated rat. Metabolism 49:1390-1394.

16. Brondum, E., Nilsson, H., and Aalkjaer, C. 2005. Functional abnormalities in isolated arteries from Goto-Kakizaki and streptozotocin-treated diabetic rat models. Horm. Metab. Res. 37:56-60.

17. Auclair C, Voisin E (1985). Nitroblue tetrazolium reduction. In: Greenvvald RA (ed) Handbook of methods for oxygen radical research. CRC Press Une, Boca Raton, pp 123-32.

18. Pick E, Keisari Y. A simple colorimetric method for the measurment of hydrogen peroxide produced by cells in culture. J Immunol Methods 1980; 38:161-70.

19. Green LC, Wagner DA, Glogowski J, Skipper PL, Wishnok JS, Tannenbaum SR. Analysis of nitrate, nitrite and [15 N] nitrate in biological fluids. Anal Biochem 1982; 26: 131-138.

20. Ohkawa H, Ohishi N, Yagi K. Assay for lipid peroxides in animal tissues by thiobarbituric acid reaction. Anal Biochem 1979; 95:351-8. 
21. Aebi H. Catalase in vitro. Methods in Enzymology. 1984; 105: 121-6.

22. Beutler E. Superoxide dismutase. In: Beutler E, eds. Red Cell Metabolism. A Manual of Biochemical Methods. Philadelphia, Grune \& Stratton:PA; 1984: 83- 5.

23. Beutler E, Duron O, Kelly BM. Improved method for the determination of blood. Glutathione. J Lab Clin Med. 1963; 61: 882-8.

24. Akash MS, Rehman K, Chen S. Role of inflammatory mechanisms in pathogenesis of type 2 diabetes mellitus. J Cell Biochem. 2013;114(3):525-31.

25. Rehman K, Akash MSH. Mechanism of Generation of Oxidative Stress and Pathophysiology of Type 2 Diabetes Mellitus: How Are They Interlinked? J Cell Biochem. 2017;118(11):3577-85.

26. Flegal KM, Graubard BI, Williamson DF, Gail MH. Cause-specific excess deaths associated with underweight, overweight, and obesity. JAMA. 2007;298(17):2028-37.

27. Sakuraba H, Mizukami H, Yagihashi N, Wada R, Hanyu C, Yagihashi S. Reduced beta-cell mass and expression of oxidative stress-related DNA damage in the islet of Japanese Type II diabetic patients. Diabetologia. 2002;45(1):85-96.

28. Shin CS, Moon BS, Park KS, Kim SY, Park SJ, Chung MH, Lee HK. Serum 8-hydroxy-guanine levels are increased in diabetic patients. Diabetes Care. 2001;24(4):733-7.

29. Demircan N, Gurel A, Armutcu F, Unalacak M, Aktunc E, Atmaca $\mathrm{H}$. The evaluation of serum cystatin $\mathrm{C}$, malondialdehyde, and total antioxidant status in patients with metabolic syndrome. Med Sci Monit. 2008;14(2):CR97-101.

30. Nowotny K, Jung T, Höhn A, Weber D, Grune T. Advanced glycation end products and oxidative stress in type 2 diabetes mellitus. Biomolecules. 2015;5(1):194222.

31. Valko M, Leibfritz D, Moncol J, Cronin MT, Mazur M, Telser J. Free radicals and antioxidants in normal physiological functions and human disease. Int $\mathrm{J}$ Biochem Cell Biol.2007;39(1):44-84.

32. Asmat U, Abad K, Ismail K. Diabetes mellitus and oxidative stress-A concise review. Saudi Pharm J. 2016;24(5):547-53

33. Hopps E, Noto D, Caimi G, Averna MR. A novel component of the metabolic syndrome: the oxidative stress. Nutr Metab Cardiovasc Dis. 2010;20(1):72-7.

34. Perez-Matute P, Zulet MA, Martínez JA. Reactive species and diabetes: counteracting oxidative stress to improve health. Curr Opin Pharmacol. 2009;9(6):771-9.

35. Murakami K, Kondo T, Ohtsuka Y, Fujiwara Y, Shimada M, Kawakami Y. Impairment of glutathione metabolism in erythrocytes from patients with diabetes mellitus. Metabolism. 1989;38(8):753-8.

36. Turner RC, Cull CA, Frighi V, Holman RR. Glycemic control with diet, sulfonylurea, metformin, or insulin in patients with type 2 diabetes mellitus: progressive requirement for multiple therapies (UKPDS 49). UK Prospective Diabetes Study (UKPDS) Group. JAMA. 1999;281(21):2005-12.

37. Fisman EZ, Motro M, Tenenbaum A. Non-insulin antidiabetic therapy in cardiac patients: current problems and future prospects. Adv Cardiol. 2008; 45:154-170.

38. Kottenberg E, Thielmann M, Kleinbongard P, Frey UH, Heine T, Jakob H, Heusch G, Peters J. Myocardial protection by remote ischaemic pre-conditioning is abolished in sulphonylurea-treated diabetics undergoing coronary revascularisation. Acta Anaesthesiol Scand. 2014;58(4):453-62.

39. Green BD, Flatt PR, Bailey CJ. Dipeptidyl peptidase IV (DPP IV) inhibitors: a newly emerging drug class for the treatment of type 2 diabetes. Diabetes and vascular disease research. 2006; 3(3): 159-65.

40. Tatosian DA, Guo Y, Schaeffer AK, Gaibu N, Popa S, Stoch A, Langdon RB, Kauh EA. Dipeptidyl peptidase4 inhibition in patients with type 2 diabetes treated with saxagliptin, sitagliptin, or vildagliptin. Diabetes Therapy. 2013; 4(2): 431-42.

41. Sherif IO, Al-Shaalan NH. Vildagliptin Attenuates Hepatic Ischemia/Reperfusion Injury via the TLR4/NF-кB Signaling Pathway. Oxid Med Cell Longev. 2018; 2018:3509091.

42. El-Kashef DH, Serrya MS. Sitagliptin ameliorates thioacetamide-induced acute liver injury via modulating TLR4/NF-KB signaling pathway in mice. Life Sci. 2019; 228:266-273.

43. Kelany ME, Hakami TM, Omar AH, Abdallah MA. Combination of Sitagliptin and Insulin against Type 2 Diabetes Mellitus with Neuropathy in Rats: Neuroprotection and Role of Oxidative and Inflammation Stress. Pharmacology. 2016;98(5-6):242-250.

44. Helal MG, Zaki MMAF, Said E. Nephroprotective effect of saxagliptin against gentamicin-induced nephrotoxicity, emphasis on anti-oxidant, anti-inflammatory and anti-apoptic effects. Life Sci. 2018; 208:64-71.

45. Liu Y, Zhang Z, Chen R, Sun J, Chen H. Therapeutic effect of saxagliptin in rat models of nonalcoholic fatty liver and type 2 diabetes. Nan Fang Yi Ke Da Xue Xue Bao. 2014;34(6):862-8.

46. Refaat R, Sakr A, Salama M, El Sarha A. Combination of Vildagliptin and Pioglitazone in Experimental Type 2 Diabetes in Male Rats. Drug Dev Res. 2016;77(6):3009. 